\title{
Do you respond sincerely? How sellers' responses to online reviews affect customer relationship and repurchase intention
}

\author{
Xiaofei $\mathrm{Li}^{1}$, Baolong $\mathrm{Ma}^{2^{*}}$ and Rubing $\mathrm{Bai}^{2}$
}

\footnotetext{
* Correspondence: mablv5@sina. com

${ }^{2}$ School of Management and Economics, Beijing Institute of Technology, Beijing 100081, China Full list of author information is available at the end of the article
}

\begin{abstract}
For many online businesses, online reviews are crucially important to managing reputation, word-of-mouth sales, and, ultimately, their survival. Hence, more and more online business owners are posting public responses to both positive and negative reviews. But do these responses change anything? And, if so, which types of responses are the most effective for strengthening customer relationship and increasing the chances of repeat business? With two surveys and a series of partial least squares-structural equation modeling (PLS-SEM) analyses, we tested three relevant hypotheses to answer these questions. The results show that when business replies to online reviews with promotional information, consumers perceive the seller to be self-interested, and both relationship quality and repurchase intention decrease. However, sincere responses that do not contain promotional information, such as gratitude and apology, are highly correlated to positive relationship quality and the likelihood of future repeat business. These findings enrich the academic literature on online reviews, and the recommendations stemming from our results should be of interest to any business that relies on their online reputation for survival.

Keywords: Online business, Online reviews, Seller responses to online reviews, Promotional information, Relationship quality, Repurchase intention, Partial least squares-structural equation modeling (PLS-SEM)
\end{abstract}

\section{Introduction}

Across entrepreneurial thinking, the marketing disciplines, and academic studies, it is becoming increasingly clear that there are significant correlations between online reviews, consumer decision making, and sales-especially in the retail and service sectors (e.g., Cheng et al. 2019; Filieri et al. 2018; Nguyen and Nguyen 2020; Zhang et al. 2019). In fact, for many online business, maintaining a "4- to 5-star reputation" on prime e-commerce and review platforms is essential to the firm's survival (Rose and Blodgett 2016) - Taobao for products, Dianping.com for services, to name just a few.

(C) The Author(s). 2020 Open Access This article is licensed under a Creative Commons Attribution 4.0 International License, which permits use, sharing, adaptation, distribution and reproduction in any medium or format, as long as you give appropriate credit to the original author(s) and the source, provide a link to the Creative Commons licence, and indicate if changes were made. The images or other third party material in this article are included in the article's Creative Commons licence, unless indicated otherwise in a credit line to the material. If material is not included in the article's Creative Commons licence and your intended use is not permitted by statutory regulation or exceeds the permitted use, you will need to obtain permission directly from the copyright holder. To view a copy of this licence, visit http://creativecommons.org/licenses/by/4.0/. 
In turn, much attention has been paid to intervention strategies for managing and guiding online reviews, especially negative reviews, toward desirable outcomes (Sparks and Bradley 2017). Often, a key aspect of these strategies is to respond to these reviews directly, both positive and negative-the idea being that responses to positive reviews should deliver appreciation, while responses to negative reviews should manage the complaint (Wang and Chaudhry 2018). Recent studies have explored sellers' responses to negative reviews, generally reaching the consensus that responding is beneficial for the sellers. According to Qing et al. (2018), responding to a negative review significantly improves purchasing intention. Rose and Blodgett (2016) note that, when a service failure has been caused by a controllable factor, responses by management can mitigate the adverse effects of negative reviews.

Additionally, the response can have a strong impact on consumer perceptions of the business (Esmark Jones et al. 2018; Qing et al. 2018; Wang and Chaudhry 2018; Wang et al. 2016). Sparks and Browning (2011), for example, find that, in the hotel sector, customer-to-provider feedback systems improve both consumer satisfaction and occupancy rates, while the results of Dawar and Pillutla's (2000) study on general brand management indicate that a firm is more likely to improve consumer attitudes after an incident if the firm directly responds to the customer's complaint in a public forum. Interestingly, $\mathrm{Gu}$ and Ye's (2014) research suggests that responses have more impact when the consumer is less satisfied and, moreover, that responding to one customer's complaint but not another's can significantly increase dissatisfaction on the part of the complainant (likely due to the indignance of being ignored where others were not). However, although the importance of, and methods by which, sellers should respond to online reviews have been well researched, the types of the responses have not.

In marketing practice, the two most typical responses to online reviews are to: (1) show gratitude for favorable feedback (e.g. "We appreciate your satisfaction and support, thank you!") or to apologize (e.g. "We are sorry the fabric makes you feel uncomfortable."); (2) promote the brand or publicize an upcoming event, e.g., "On 11th Dec, our store will be holding a Winter Sale with up to $50 \%$ off!". In practice, sellers often combine more than one of these sentiments into a response, e.g., "Thank you very much for your support. You may be interested in our upcoming Winter Sale with up to $50 \%$ off."

But how do customers perceive these responses? In a given situation, which types of responses help to strengthen customer relationship? And do they just help to manage reputational issues so as to avoid losing new customers? In this research, we address two of these concerns:

1. Does including promotional information in a response to an online review affect customer relationship quality and repurchase intention?

2. What perceptions do customers develop about a business when responses to positive/negative online reviews include/do not include promotional information?

Through partial least squares-structural equation modeling (PLS-SEM) and tests for alternative explanations, we find that when online business replies to online reviews with promotional information, both relationship quality and repurchase intention decrease, while sincere responses that do not contain promotional information are highly correlated to customer relationship quality and the likelihood of future repeat business. 
The remainder of this paper is structured as follows. Section 2 discusses the relevant literature and develops the hypotheses. Sections 3 presents the empirical analyses, the alternative explanation tests, and our findings. The paper concludes in section 4 with a discussion on the theoretical and managerial implications of our conclusions.

\section{Literature review and hypothesis development}

Given the role of driving sales, numerous online sellers have taken actions to manage online reviews by responding to consumer reviews (Chang et al. 2020; Ullrich and Brunner 2015). Some researcers have investigated the effects of response to a negative consumer review (Qing et al. 2018; Ullrich and Brunner 2015) or a positive consumer review (Wang and Chaudhry 2018). Wang and Chaudhry (2018) contend that while replying to negative comments by customers can be seen as complaint management (see also Sparks and McColl-Kennedy 2001), responding to positive comments creates an emotional interaction, which is an effective way of increasing customer satisfaction (Tsai and Huang 2002). At the other end of the spectrum, Smith et al. (1999) and Walster et al. (1973) point out that psychological compensation, such as an apology, can improve a customer's perceptions of fairness, and thus, increase the chances of successfully resolving a complaint.

However, the underlying assumption that drives such conclusions is that the customer considers the gratitude or apology to be sincere (Tang et al. 2010; Tu et al. 2009). We intuit that consumers see advertising as a largely self-interested action (Olbrich and Schultz 2014). Although providing customers with information about promotions is a common and often valued practice for consumers, including promotional information in a response to an online review may undermine any benefits derived from the thanks or apology. When a customer perceives a company's affective delivery or apology is disingenuous, his/her impression toward the company may be negatively influenced (Groth et al. 2009). A response without promotion information may lead consumers to perceive that the purpose of this response is just to delivery seller's gratitude or apology. However, if a seller's response to a online review, both positive review and negative review, is followed by promotional information, consumers will perceive that the purpose of the response is only to advertise itself and to sale products, rather than expressing a feeling of gratitude/sincere apology or solving the problem. Based on the above arguments, the following hypothesis is proposed:

\section{Hypothesis 1: The type of response to online reviews, both a positive review and a} negative review, can affect customer perceived purpose of response.

Based on the norm of reciprocity, strengthening the emotional bond that a business built with its customers can increase the possibility of more purchases in the future (Gouldner 1960), and seeing that the seller appreciates the positive review given is one such way to reinforce this bond (Palmatier et al. 2009). It follows then that customers will be more likely to repurchase from that business. Conversely, attempts to address a negative review with an invitation to "try purchasing again" through promotional information are likely to undermine this bond, thus decreasing customers' repurchase intention. Therefore, the following hypotheses are proposed: 
Hypothesis 2: Customer perceived purpose of response weakens customer relationship quality.

Hypothesis 3: Customer perceived purpose of response reduces repurchase intention.

The conceptual framework of the study is shown in Fig. 1.

\section{Data collection and hypotheses testing}

Controlling for the effects of customer satisfaction and online reviews type, we tested our predictions over two separate studies. Study 1 examines the effects of responses to online reviews on relationship quality and repurchase intention. Study 2 not only generalizes these findings to another scenario to extend validity but also adds a control scenario where promotional information is provided on its own, i.e., not in response to an online review. This is to rule out the influence of any general appeal or aversion to advertising by the participants.

\section{Study 1: effects on relationship quality and repurchase intention}

\section{Data collection}

We commissioned Sojump, an online survey company, to help us collect the research data for Study 1. Sojump provides access to data of a quality equivalent to traditional sampling approaches (Berinsky et al. 2012). Respondents who completed the questionnaire were rewarded with Sojump points. During data collection, Sojump used "trap" questions, for example, $3 X+4=13, X=$ ? to rule out invalid questionnaires. Further, to rule out the effects of online reviews itself, we took the type of online reviews as a control variable. Thus, in Study 1, 442 participants were randomly assigned to one of four online review-response scenarios in a $2 \times 2$ between-subjects design: the seller's response with and without promotional information, and the seller's response to positive and negative reviews.

On the first page of the questionnaire, participants were asked to imagine themselves in an online shopping situation. Some were given a satisfactory experience; others unsatisfactory, as follows. The positive experience was described as: "Last month, you bought a pair of jeans online at a price of 300 yuan. After receiving the jeans, you found them to be well-made, well-rounded with a good fit, and very comfortable to wear. Therefore, you want to post a positive comment about the pants on the website. Please write down your comments." The description of the negative experience was:

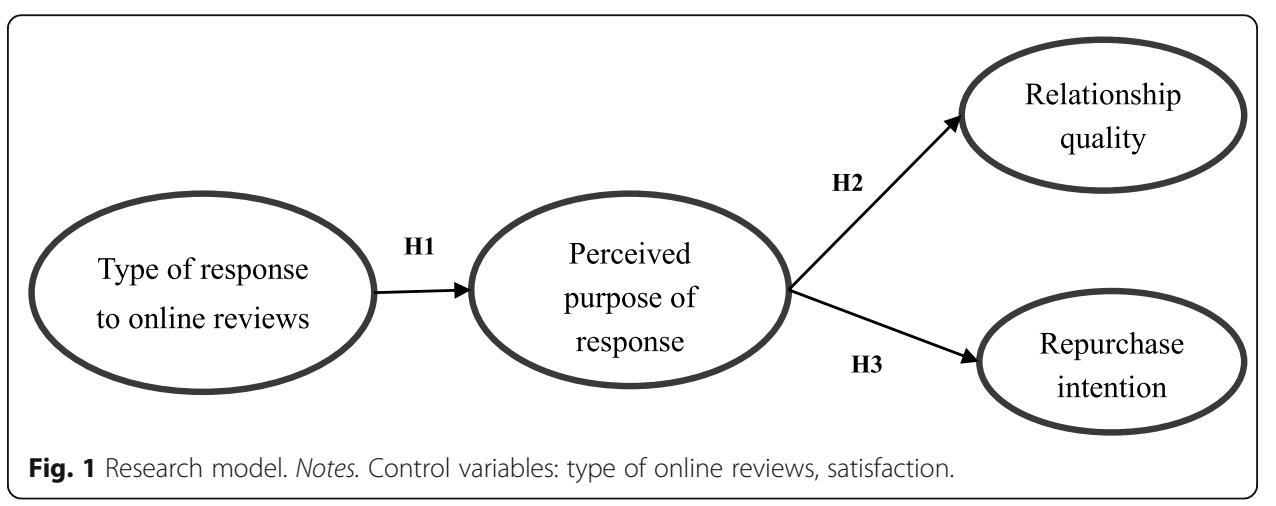


"Last month, you bought a pair of jeans online at a price of 300 yuan. After receiving the goods, you found they had rough workmanship, uneven lines, and an unsatisfactory fit. They looked terrible and were uncomfortable to wear. Therefore, you want to post a negative comment about the jeans on the website. Please write down your comments." The reason why participants were asked to write their own positive and negative reviews was to engage them more deeply in the scenario as a way to increase the integrity and authenticity of their answers to the survey.

The seller's response to the participant's review was provided on the second page of the questionnaire. The responses assigned to each of the four scenarios are given in Additional file 1.

\section{Variables and measurements}

The survey design is shown in Table 1. Participants were asked to score their agreement with various statements on a 7-point Likert scale (where $1=$ strongly disagree, 7 = strongly agree). Relationship quality was measured against eight statements adapted from De Wulf et al. (2001). Three more constructs-repurchase intention, perceived purpose of response, and customer satisfaction-were each measured against one statement. In addition to the constructs, there was also a dummy variable to indicate whether the seller's response included promotional information $(=1)$ or not $(=0)$. Further, we conducted two independent analyses: one for those given a satisfactory experience (the positive review group), and another for those given an unsatisfactory experience (the negative review group).

An initial list of sentiment statements for each of the constructs was discussed with one professor and eight postgraduate students of marketing. Revisions and additions were made to the list as a result. Then the entire item pool was tested in qualitative interviews, followed by a pretest with 35 graduate students and a Ph.D. Candidate at a university in Beijing, China. The final survey instrument was constructed by selecting and modifying the statements according to feedback from the interviews and the pretest. Because the questionnaire was translated into Chinese from English, we implemented back-translations to ensure accuracy (Brislin 1970).

Table 1 Constructs and measurements

\begin{tabular}{ll}
\hline Construct & Measurement \\
\hline $\begin{array}{l}\text { Relationship quality (De Wulf } \\
\text { et al. 2001) }\end{array}$ & $\begin{array}{l}\text { As a regular customer, I have a high-quality relationship with this store. } \\
\text { I am satisfied with the relationship I have with this store. } \\
\text { I have trust in this store. } \\
\text { This store gives me a feeling of trust. } \\
\text { This store gives me a trustworthy impression. } \\
\text { I am willing to remain a customer of this store with more time and energy. } \\
\text { I intend to keep a relationship with this store over the long term. } \\
\text { I feel loyal towards this store. }\end{array}$ \\
$\begin{array}{ll}\text { Repurchase intention (Tsai and } \\
\text { Huang 2007) }\end{array}$ \\
$\begin{array}{l}\text { Perceived purpose of response } \\
\text { Satisfaction (Fornell et al. 1996) }\end{array}$ & $\begin{array}{l}\text { The purpose of the seller's response is to promote themselves rather than } \\
\text { sincerely deliver gratitude/an apology. }\end{array}$ \\
\hline
\end{tabular}




\section{Hypothesis tests: study 1}

We chose a PLS-SEM analysis for Study 1 because the sample size was relatively small, and the variables do not follow particularly normal distributions. PLS is suitable for small samples and does not rest on the assumption of normal distributions (Hair et al. 2011). Plus, when appropriately applied, PLS-SEM provides more robust estimations of the structural model than covariance-based SEM (CB-SEM) (Reinartz et al. 2009). Using SmartPLS 3.0 software, we analyzed the research data, following the instructions of Hair et al. (2011), who recommend calculating the significance of the model estimates through a bootstrapping procedure with 5000 samples.

Measurement model The descriptive statistics and correlation coefficients for the positive and negative review groups are shown in Tables 2 and 3, respectively.

Looking at the positive review group first, the Cronbach's alpha for relationship quality was 0.874 , exceeding the benchmark of 0.7 , which confirms good internal consistency for all measurement items. All factor loadings were significant at over 0.7 $(p<0.001)$. We assessed convergent validity using average variance extracted (AVE) and composite reliability (CR), and discriminant validity was assessed following Fornell and Larcker's (1981) test, which states that the AVE of each construct should exceed its squared correlation to any other construct. An AVE of 0.52 and a CR of 0.90 verify both construct and discriminant validity. Further, with a maximum of 1.17 variance inflation factor (VIF) among all constructs, much lower than the recommended value of 5 , multicollinearity is not a threat in this research. The standardized root mean square residual (SMSR) was 0.058, which is slightly higher than the standard 0.05 .

In terms of the negative review group, the Cronbach's alpha for relationship quality was 0.955 , which exceeds the benchmark of 0.7 , confirming good internal consistency for all items. All factor loadings were significant at over $0.7(p<0.001)$. Both convergent and discriminant validity were assured with an AVE of 0.76 and a CR of 0.96. The maximum VIF was 1.06, again dismissing multicollinearity as a threat. Last, the SMSR was 0.034 , lower than the standard 0.05 , illustrating a satisfactory model fit.

Structural model The primary evaluation criteria for the structural model were $R^{2}$ measures, plus the level of significance and path coefficients (Hair et al. 2011). Hair et al. (2011) propose that 0.20 is a very high $R^{2}$ in customer behavior research. As can be seen from Table 4, an $R^{2}$ of 0.15 for relationship quality and 0.11 for repurchase intention with the positive review group, and 0.20 and 0.30 respectively for the negative review group (see Table 5), both reach an acceptable level of $R^{2}$. Thus, H1 is supported $\left(\beta_{\text {response to positive review }}=0.276, p<0.001 ; \beta_{\text {response to negative review }}=0.169, p<0.05\right.$ ).

Table 2 Study 1 statistics and correlation coefficients-positive reviews

\begin{tabular}{lccllll}
\hline Variable & Mean SD & $\begin{array}{l}\text { Perceived purpose of } \\
\text { response }\end{array}$ & $\begin{array}{l}\text { Relationship } \\
\text { quality }\end{array}$ & $\begin{array}{l}\text { Repurchase } \\
\text { intention }\end{array}$ & Satisfaction \\
\hline $\begin{array}{l}\text { Perceived purpose of } \\
\text { response }\end{array}$ & 4.46 & 1.49 & - & & \\
Relationship quality & 5.27 & 0.81 & -0.28 & - & \\
Repurchase intention & 5.87 & 0.90 & -0.19 & 0.58 & - & - \\
Satisfaction & 6.00 & 1.28 & -0.04 & 0.21 & 0.27 & - \\
\hline
\end{tabular}


Table 3 Study 1 statistics and correlation coefficients - negative reviews

\begin{tabular}{lccllll}
\hline Variable & Mean SD & $\begin{array}{l}\text { Perceived purpose of } \\
\text { response }\end{array}$ & $\begin{array}{l}\text { Relationship } \\
\text { quality }\end{array}$ & $\begin{array}{l}\text { Repurchase } \\
\text { intention }\end{array}$ & Satisfaction \\
\hline $\begin{array}{l}\text { Perceived purpose of } \\
\text { response }\end{array}$ & 4.46 & 1.69 & - & & \\
Relationship quality & 2.37 & 1.29 & -0.32 & - & \\
Repurchase intention & 2.08 & 1.38 & -0.28 & 0.73 & - & - \\
Satisfaction & 1.89 & 1.34 & -0.08 & 0.45 & 0.34 & - \\
\hline
\end{tabular}

When a store's responses to online reviews contain promotional information, consumers perceive that the intention is to promote the store rather than sincerely express gratitude or apologize to their customers. $\mathrm{H} 2$ and $\mathrm{H} 3$ are also supported; with $\mathrm{H} 2$ (relationship quality) at $\beta_{\text {response to positive review }}=-0.289, p<0.001 ; \beta_{\text {response to negative review }}=$ $-0.272, p<0.001$ and $\mathrm{H} 3$ (repurchase intention) at $\beta_{\text {response to positive review }}=-0.182$, $p<0.01 ; \beta_{\text {response to negative review }}=-0.255, p<0.001$. These results indicate that if consumers perceive the motivation behind a seller's response to be out of self-interest, relationship quality degrades, and customers feel less likely to purchase from that business again (Table 5).

\section{Study 2: alternative explanation tests}

Study 2 was designed to replicate Study 1 with another scenario to extend external validity and isolate the effects of promotional information not given in response to an online review. Our main purpose was to rule out any general aversion to advertising as an influence over the participants' views.

\section{Data collection}

The data collection procedure for Study 2 was similar to Study 1. Three hundred ninety-two Chinese residents were recruited from Sojump and compensated for their time with Sojump points. The participants were randomly assigned to one of four scenarios in the same $2 \times 2$ between-subjects design as Study 1 (i.e., with and without promotional information for positive and negative reviews), as well as two promotion-only scenarios as a control to rule out the argument that promotional information on its own creates consumer aversion that impacts decision-making.

Table 4 Study 1 hypothesis test results-positive reviews

\begin{tabular}{llll}
\hline Hypothesis & $\begin{array}{l}\text { Parameter } \\
\text { estimate }\end{array}$ & $\begin{array}{l}T \text { statistics } \\
(|\mathbf{O} / \mathbf{S T D E V}|)\end{array}$ & $\boldsymbol{p}$ \\
\hline H1 $\quad \begin{array}{l}\text { Type of response to online reviews } \rightarrow \text { Perceived purpose of } \\
\text { response }\end{array}$ & $0.276^{* * * *}$ & 4.53 & 0.000 Support \\
H2 Perceived purpose of response $\rightarrow$ Relationship quality & $-0.289^{* * *}$ & 4.151 & 0.000 Support \\
H3 Perceived purpose of response $\rightarrow$ Repurchase intention & $-0.182^{* *}$ & 3.026 & 0.002 Support \\
$\quad$ Satisfaction $\rightarrow$ Relationship quality & $0.215^{*}$ & 2.291 & 0.022 \\
$\quad$ Satisfaction $\rightarrow$ Repurchase intention & $0.255^{* *}$ & 2.625 & 0.009 \\
$R^{2}$ for relationship quality $0.15 \Delta R^{2}$ for relationship quality 0.13 & & & \\
$R^{2}$ for repurchase intention $0.11 \Delta R^{2}$ for repurchase intention 0.10 & & & \\
${ }^{*} p<0.05,{ }^{* *} p<0.01,{ }^{* * *} p<0.001$ & &
\end{tabular}


Table 5 Study 1 hypothesis test results-negative reviews

\begin{tabular}{llll}
\hline Hypothesis & $\begin{array}{l}\text { Parameter } \\
\text { estimate }\end{array}$ & $\begin{array}{l}\boldsymbol{T} \text { statistics } \\
(|\mathbf{O} / \mathbf{S T D E V}|)\end{array}$ & $\boldsymbol{p}$ \\
\hline H1 $\quad \begin{array}{l}\text { Type of response to online reviews } \rightarrow \text { Perceived purpose of } \\
\text { response }\end{array}$ & $0.169^{*}$ & 2.558 & 0.011 Support \\
H2 Perceived purpose of response $\rightarrow$ Relationship quality & $-0.272^{* * * *}$ & 4.417 & 0.000 Support \\
H3 Perceived purpose of response $\rightarrow$ Repurchase intention & $-0.255^{* * *}$ & 3.749 & 0.000 Support \\
$\quad$ Satisfaction $\rightarrow$ Relationship quality & $0.416^{* * *}$ & 5.167 & 0.000 \\
$\quad$ Satisfaction $\rightarrow$ Repurchase intention & $0.311^{* * *}$ & 3.786 & 0.000 \\
$R^{2}$ for relationship quality $0.20 \Delta R^{2}$ for relationship quality 0.18 & & & \\
$R^{2}$ for repurchase intention $0.30 \Delta R^{2}$ for repurchase intention 0.28 & & & \\
${ }^{*} p<0.05,{ }^{* * *} p<0.001$ & &
\end{tabular}

In this scenario, participants were asked to imagine that they purchased neck massager at a cost of 500 yuan because of neck discomfort. They were also given either a positive or a negative review about the neck massager. In the high satisfaction group, the review is positive: "This neck massager is exquisitely made, comfortable to wear and has a heating function. The massage force is moderate and provides a very comfortable neck massage." The review for the low satisfaction group is negative: "This neck massager is roughly made, uncomfortable to wear and has no heating function. The massage force is too weak and does not provide a comfortable neck massage at all." The seller's response to the review appears on the second page of the questionnaire. Additional file 2 shows the response allocated to each scenario, plus the promotion-only text. The variables and measurements were the same as for Study 1.

\section{Hypothesis tests: study 2}

Measurement model To evaluate the psychometric adequacy of the constructs, we conducted a confirmatory factor analysis. The results, shown in Tables 6 and 7, illustrate that all factor loadings were significant $(p<0.001)$, ranging from 0.71 to 0.90 . The Cronbach's alphas for relationship quality for the positive and negative review groups were 0.91 and 0.96 , respectively. The CRs were 0.92 and 0.96 , which exceeds the benchmark of 0.70, suggesting that the measures are reliable. Relationship quality had an AVE well above the recommended value of 0.50 , ranging from 0.58 to 0.75 , and, according to the Fornell and Larcker's (1981) test, all the constructs have discriminant validity. The VIFs were lower than the recommended value of 5 (the maximum was 1.03), verifying that multicollinearity is not a threat.

Table 6 Study 2 statistics and correlation coefficients_-positive reviews

\begin{tabular}{lccllll}
\hline Variable & Mean SD & $\begin{array}{l}\text { Perceived purpose of } \\
\text { response }\end{array}$ & $\begin{array}{l}\text { Relationship } \\
\text { quality }\end{array}$ & $\begin{array}{l}\text { Repurchase } \\
\text { intention }\end{array}$ & Satisfaction \\
\hline $\begin{array}{l}\text { Perceived purpose of } \\
\text { response }\end{array}$ & 4.47 & $1.49-$ & & & \\
Relationship quality & 5.30 & 0.91 & -0.21 & - & & \\
Repurchase intention & 5.74 & 1.02 & -0.13 & 0.60 & - & \\
Satisfaction & 6.24 & 0.81 & -0.04 & 0.35 & 0.38 & - \\
\hline
\end{tabular}


Table 7 Study 2 statistics and correlation coefficients - negative reviews

\begin{tabular}{lccllll}
\hline Variable & Mean SD & $\begin{array}{l}\text { Perceived purpose of } \\
\text { response }\end{array}$ & $\begin{array}{l}\text { Relationship } \\
\text { quality }\end{array}$ & $\begin{array}{l}\text { Repurchase } \\
\text { intention }\end{array}$ & Satisfaction \\
\hline $\begin{array}{l}\text { Perceived purpose of } \\
\text { response }\end{array}$ & 5.10 & 1.46 & - & & \\
Relationship quality & 2.90 & 1.43 & -0.34 & - & \\
Repurchase intention & 2.53 & 1.65 & -0.29 & 0.80 & - & - \\
Satisfaction & 1.82 & 1.28 & -0.17 & 0.60 & 0.58 & - \\
\hline
\end{tabular}

Structural model The results of the hypothesis tests are consistent with the findings of Study 1 (see Tables 8 and 9). H1 is again supported $\left(\beta_{\text {response to positive review }}=0.205, p<0.01\right.$; $\beta_{\text {response to negative review }}=0.344, p<0.001$ ), from which we conclude that including promotional information in response to an online review adversely affects customer perceived purpose of response. Further, these perceptions significantly weaken relationship quality, in support of $\mathrm{H} 2\left(\beta_{\text {response to positive review }}=-0.200, p<0.01 ; \beta_{\text {response to negative review }}=-0.248\right.$, $p<0.01)$. However, the effect of customer perceptions on repurchase intention in the positive review group was not strongly significant $(\beta=-0.115, p<0.1)$ and yet extremely significant with the negative review group $(\beta=-0.206, p<0.05)$. Therefore, we only find partial support for $\mathrm{H} 3$.

In the case of the seller responses to positive reviews, the model explains $16 \%$ of the variance in relationship quality (Adjusted $R^{2}=0.14$ ) and $16 \%$ of the variance in repurchase intention (Adjusted $R^{2}=0.14$ ). The fit of the model was good, with an SRMR of 0.05 . With the negative reviews, the model explains $42 \%$ of the variance in consumer expectation (Adjusted $R^{2}=0.42$ ) and $37 \%$ of the variance in product return (Adjusted $R^{2}=0.37$ ). The SRMR was 0.036 , which indicates the fit of the model was good.

Among the control variables, we found that satisfaction had a positive and significant coefficient, signaling that consumer satisfaction increases the strength of customer relationship and repurchase intention. The analysis of variance with the control scenario revealed a significant difference in perceptions between promotional information on its own and when combined into a response to an online review. For relationship quality, the impact was $\mathrm{M}_{\text {yes }}=3.96, \mathrm{M}_{\mathrm{no}}=4.35 ; \mathrm{F}(1,431)=4.42(p<0.05)$. On repurchase intention, the impact was $\mathrm{M}_{\text {yes }}=3.99, \mathrm{M}_{\text {no }}=4.47 ; \mathrm{F}(1,431)=7.28(p<0.01)$. Both indicate a substantial reduction in favor when promotional information is included in a response to an online review (Tables 8 and 9).

\section{Conclusion}

In this study, we explored whether including promotional content in responses to online reviews affects customer relationship and repurchase intention. From a survey of almost 1000 participants across two hypothetical online shopping scenarios, our results show that customers perceive responses that include promotional information to be self-serving and disingenuous to the detriment of both the customer relationship and the potential for repeat business. These findings provide interesting implications for academics, business owners, and managers, as discussed next. 
Table 8 Study 2 hypothesis test results-positive reviews

\begin{tabular}{|c|c|c|c|c|c|}
\hline & Hypothesis & $\begin{array}{l}\text { Parameter } \\
\text { estimate }\end{array}$ & $\begin{array}{l}T \text { statistics } \\
(|\mathrm{O} / \mathrm{STDEV}|)\end{array}$ & $p$ & Result \\
\hline $\mathrm{H} 1$ & $\begin{array}{l}\text { Type of response to online reviews } \rightarrow \text { Perceived purpose of } \\
\text { response }\end{array}$ & $0.205^{* *}$ & 3.00 & 0.003 & Support \\
\hline $\mathrm{H} 2$ & Perceived purpose of response $\rightarrow$ Relationship quality & $-0.200^{* *}$ & 2.986 & 0.003 & Support \\
\hline $\mathrm{H} 3$ & Perceived purpose of response $\rightarrow$ Repurchase intention & -0.115 & 1.726 & 0.084 & $\begin{array}{l}\text { Partly } \\
\text { support }\end{array}$ \\
\hline & Satisfaction $\rightarrow$ Relationship quality & $0.340^{* * *}$ & 5.940 & 0.000 & \\
\hline & Satisfaction $\rightarrow$ Repurchase intention & $0.376^{* * *}$ & 6.277 & 0.000 & \\
\hline \multicolumn{6}{|c|}{$R^{2}$ for relationship quality $0.16 \Delta R^{2}$ for relationship quality 0.14} \\
\hline \multicolumn{6}{|c|}{$R^{2}$ for repurchase intention $0.16 \Delta R^{2}$ for repurchase intention 0.14} \\
\hline
\end{tabular}

\section{Theoretical contributions}

Although many scholars have studied the role of online reviews in e-commerce marketing (e.g., Chevalier and Mayzlin 2006; Yin et al. 2014; Zhu and Zhang 2010); explored the effects of sellers' response to negative consumer reviews (e.g., Gu and Ye 2014; Wang and Chaudhry 2018); and the effectiveness of responses (e.g., Sparks and Bradley 2017), limited research has focused on how the types of responses affect consumer behavior, and particularly relationship management, as well as repurchase intention. Our findings highlight that responding to online reviews appropriately can be a key aspect of customer relationship management strategies. When used correctly, these responses can be a powerful promoter of beneficial customer behaviors.

This research enriches and deepens the existing theories in two ways. First, it draws attention to the importance of what a seller says in response to a review. What is most widely recognized at present is that responding to a review promptly is the critical factor, especially to complaints. Our findings enrich and expand the existing research to include the types of responses and the impact of responses to positive reviews as well as negative reviews.

Second, we provide evidence to support the assumptions made by Wang and Chaudhry (2018), Sparks and McColl-Kennedy (2001), Tsai and Huang (2002) and others that sincerity is key to the success of a customer relationship management strategy. Our respondents were neutral to promotional information presented on its own. However, when included in a response to an online review-positive or negative-their

Table 9 Study 2 hypothesis test results - negative reviews

\begin{tabular}{llll}
\hline Hypothesis & $\begin{array}{l}\text { Parameter } \\
\text { estimate }\end{array}$ & $\begin{array}{l}\boldsymbol{T} \text { statistics } \\
(|\mathbf{O} / \mathbf{S T D E V}|)\end{array}$ & $\boldsymbol{p}$ Result \\
\hline H1 $\begin{array}{l}\text { Type of response to online reviews } \rightarrow \text { Perceived purpose of } \\
\text { response }\end{array}$ & $0.344^{* * * *}$ & 5.371 & 0.000 Support \\
H2 Perceived purpose of response $\rightarrow$ Relationship quality & $-0.248^{* *}$ & 3.391 & 0.001 Support \\
H3 Perceived purpose of response $\rightarrow$ Repurchase intention & $-0.206^{*}$ & 2.593 & 0.010 Support \\
$\quad$ Satisfaction $\rightarrow$ Relationship quality & $0.561^{* * * *}$ & 9.548 & 0.000 \\
$\quad$ Satisfaction $\rightarrow$ Repurchase intention & $0.541^{* * * *}$ & 8.830 & 0.000 \\
$R^{2}$ for relationship quality $0.42 \Delta R^{2}$ for relationship quality 0.42 & & & \\
$R^{2}$ for repurchase intention $0.37 \Delta R^{2}$ for repurchase intention 0.37 & & & \\
${ }^{*} p<0.05,{ }^{* *} p<0.01,{ }^{* * *} p<0.001$ & &
\end{tabular}


perceptions changed to ones of self-interest and seller-oriented sentiments, negating any benefits to expressing gratitude or providing an apology.

\section{Managerial implications}

Our findings yield insights for marketing practitioners as well. First, we can confirm the long-held view in marketing practice that responding to online reviews can be a very powerful part of a customer relationship management strategy. Properly responding to online reviews can not only delivery gratitude/apology to consumers, but also help sellers to cultivate good customer relationship and to induce consumer repurchase behavior.

Second, our analyses reveal very specific and operable suggestions for how to respond to a review, or to be more specific, not to respond to an online review. The results clearly indicate that promoting oneself in response to either a good review or a customer complain is not a good idea. Contrary to the expectation that satisfied customers will appreciate information about future opportunities to shop, save, experience new products, and so on. or that the misgivings of unsatisfied customers might be resolved through "a second and better" experience with the store, advertising promotions in this setting backfires. It sends a message of self-interest and insincerity, damages customer relations, and decreases repurchase intention. Therefore, we recommend that promotional information and customer feedback/response mechanisms be separated into distinctly separate communication channels.

\section{Limitations and suggestions for further research}

As with all studies, this research has several limitations that may be addressed by future research. First, due to the difficulty of assembling a sample, we developed hypothetical scenarios and collected data through a virtual survey provider. Future research might capture real online reviews and responses with follow-ups to the posters and sellers to test the conclusions of this study. Second, in current online shopping environments, a seller's responses can be seen by other consumers as well. It is a natural conclusion that the content and form of those responses will also affect the behavior of other consumers. This avenue of investigation holds a wealth of possible studies on customer relationship management. Finally, some sellers respond to reviews with one or a few template answers. This and other kinds of behaviors may also be perceived as insincere, which would be worthy of deeper study.

\section{Supplementary information}

Supplementary information accompanies this paper at https://doi.org/10.1186/s11782-020-00086-2.

Additional file 1:. The four scenarios of Study 1.

Additional file 2:. The five scenarios of Study 2.

Acknowledgements

The authors thank the FBR editor and review team for their helpful comments and suggestions for improvement.

Authors' contributions

All authors contributed equally. The author(s) read and approved the final manuscript. 


\section{Funding}

This work was supported by the Youth Program of National Natural Science Foundation of China [7200020259] National Natural Science Foundation of China [71672008] and Shuimu Scholar Program of Tsinghua University.

\section{Availability of data and materials}

Some or all data, models used during the study are available from the corresponding author by request.

\section{Competing interests}

The authors declare that they have no competing interests.

\section{Author details}

${ }^{1}$ School of Economics and Management, Tsinghua University, Beijing 100084, China. ${ }^{2}$ School of Management and Economics, Beijing Institute of Technology, Beijing 100081, China.

Received: 18 March 2020 Accepted: 15 July 2020

Published online: 07 September 2020

\section{References}

Berinsky, A. J., Huber, G. A., \& Lenz, G. S. (2012). Evaluating online labor markets for experimental research: Amazon.com's mechanical Turk. Political Analysis, 20 (3), 351-368.

Brislin, R. W. (1970). Back-translation for cross-cultural research. Journal of Cross-Cultural Psychology, 1(3), 185-216.

Chang, Y., Ku, C., \& Chen, C. (2020). Using deep learning and visual analytics to explore hotel reviews and responses. Tourism Management, 80, 1-22.

Cheng, X., Fu, S., Sun, J., Bilgihan, A., \& Okumus, F. (2019). An investigation on online reviews in sharing economy driven hospitality platforms: A viewpoint of trust. Tourism Management, 71, 366-377.

Chevalier, J. A., \& Mayzlin, D. (2006). The effect of word of mouth on sales: Online book reviews. Journal of Marketing Research, 43(3), 345-354.

Dawar, N., \& Pillutla, M. M. (2000). Impact of product-harm crises on brand equity: The moderating role of consumer expectations. Journal of Marketing Research, 37(2), 215-226.

De Wulf, K., Odekerken-Schröder, G., \& lacobucci, D. (2001). Investments in consumer relationships: A cross-country and crossindustry exploration. Journal of Marketing, 65(4), 33-50.

Esmark Jones, C. L., Stevens, J. L., Breazeale, M., \& Spaid, B. I. (2018). Tell it like it is: The effects of differing responses to negative online reviews. Psychology \& Marketing, 35(12), 891-901.

Filieri, R., McLeay, F., Tsui, B., \& Lin, Z. (2018). Consumer perceptions of information helpfulness and determinants of purchase intention in online consumer reviews of services. Information and Management, 55(8), 956-970.

Fornell, C., Johnson, M. D., Anderson, E. W., Cha, J. S., \& Bryant, B. E. (1996). The American customer satisfaction index: Nature, purpose, and findings. Journal of Marketing, 60(4), 7-18.

Fornell, C., \& Larcker, D. F. (1981). Structural equation models with unobservable variables and measurement error: Algebra and statistics. Journal of Marketing Research, 18(3), 382-388.

Gouldner, A. W. (1960). The norm of reciprocity: A preliminary statement. American Sociological Review, 25(2), 161-178.

Groth, M., Hennig-Thurau, T., \& Walsh, G. (2009). Customer reactions to emotional labor: The roles of employee acting strategies and customer detection accuracy. Academy of Management Journal, 52(5), 958-974.

Gu, B., \& Ye, Q. (2014). First step in social media: Measuring the influence of online management responses on customer satisfaction. Production and Operations Management, 23(4), 570-582.

Hair, J. F., Ringle, C. M., \& Sarstedt, M. (2011). PLS-SEM: Indeed a silver bullet. Journal of Marketing Theory and Practice, 19(2), 139-152.

Nguyen, Y. T. H., \& Nguyen, H. V. (2020). An alternative view of the millennial green product purchase: The roles of online product review and self-image congruence. Asia Pacific Journal of Marketing and Logistics.

Olbrich, R., \& Schultz, C. D. (2014). Multichannel advertising: Does print advertising affect search engine advertising? European Journal of Marketing, 48(9), 1731-1756.

Palmatier, R. W., Jarvis, C. B., Bechkoff, J. R., \& Kardes, F. R. (2009). The role of customer gratitude in relationship marketing. Journal of Marketing, 73(5), 1-18.

Qing, P., Huang, H., Razzaq, A., Tang, Y., \& Tu, M. (2018). Impacts of sellers' responses to online negative consumer reviews: Evidence from an agricultural product. Canadian Journal of Agricultural Economics, 66(4), 587-597.

Reinartz, W., Haenlein, M., \& Henseler, J. (2009). An empirical comparison of the efficacy of covariance-based and variancebased SEM. International Journal of Research in Marketing, 26(4), 332-344.

Rose, M., \& Blodgett, J. G. (2016). Should hotels respond to negative online reviews? Cornell Hospitality Quarterly, 57(4), 396410.

Smith, A. K., Bolton, R. N., \& Wagner, J. (1999). A model of customer satisfaction with service encounters involving failure and recovery. Journal of Marketing Research, 36(3), 356-372.

Sparks, B. A., \& Bradley, G. L. (2017). A "triple a" typology of responding to negative consumer-generated online reviews, Journal of Hospitality \& Tourism Research, 41(6), 719-745.

Sparks, B. A., \& Browning, V. (2011). The impact of online reviews on hotel booking intentions and perception of trust. Tourism Management, 32(6), 1310-1323.

Sparks, B. A., \& McColl-Kennedy, J. R. (2001). Justice strategy options for increased customer satisfaction in a services recovery setting. Journal of Business Research, 54(3), 209-218.

Tang, X., Jia, J., Zhou, T., \& Yin, H. (2010). Research on satisfaction recovery from service failure due to attitude defect and unfair price: A dynamic and longitudinal evaluation model based on customer win-back management. Frontiers of Business Research in China, 4(3), 380-408.

Tsai, H. T., \& Huang, H. C. (2007). Determinants of e-repurchase intentions: An integrative model of quadruple retention drivers. Information \& Management, 44(3), 231-239. 
Tsai, W. C., \& Huang, Y. M. (2002). Mechanisms linking employee affective delivery and customer behavioral intentions. Journal of Applied Psychology, 87(5), 1001-1008.

Tu, R., Chen, K., \& Lin, C. C. (2009). The dynamic role of "should expectation" in service recovery paradox. Frontiers of Business Research in China, 3(4), 583-598.

Ullrich, S., \& Brunner, C. B. (2015). Negative online consumer reviews: Effects of different responses. Journal of Product \& Brand Management, 24(1), 66-77.

Walster, E., Berscheid, E., \& Walster, G. W. (1973). New directions in equity research. Journal of Personality and Social Psychology, 25(2), 151-176.

Wang, L., Zhang, J., \& Yan, W. (2016). TOOR: A novel product title optimization method based on online reviews in ecommerce. Frontiers of Business Research in China, 9(4), 536-558.

Wang, Y., \& Chaudhry, A. (2018). When and how managers' responses to online reviews affect subsequent reviews. Journal of Marketing Research, 55(2), 163-177.

Yin, D., Bond, S. D., \& Zhang, H. (2014). Anxious or angry? Effects of discrete emotions on the perceived helpfulness of online reviews. MIS Quarterly, 38, 539-560.

Zhang, J., Weng, Z., \& Ni, N. (2019). Helping consumers to overcome information overload with a diversified online review subset. Frontiers of Business Research in China, 13(1), 1-25.

Zhu, F., \& Zhang, X. (2010). Impact of online consumer reviews on sales: The moderating role of product and consumer characteristics. Journal of Marketing, 74(2), 133-148.

\section{Publisher's Note}

Springer Nature remains neutral with regard to jurisdictional claims in published maps and institutional affiliations.

Submit your manuscript to a SpringerOpen ${ }^{\circ}$ journal and benefit from:

- Convenient online submission

- Rigorous peer review

- Open access: articles freely available online

- High visibility within the field

- Retaining the copyright to your article

Submit your next manuscript at $\boldsymbol{\nabla}$ springeropen.com 